\title{
CYPRINID HERPESVIRUS DISEASES
}

Vladimir Radosavljević ${ }^{\star}$, Jelena Maksimović-Zorić1 ${ }^{1}$, Ljubiša Veljović ${ }^{1}$, Dragana Ljubojević ${ }^{2}$, Miroslav Ćirković ${ }^{2}$ Zoran Marković ${ }^{3}$, Vesna Milićević ${ }^{1}$

${ }^{1}$ Institute of Veterinary Medicine of Serbia, Belgrade, Serbia

${ }^{2}$ Scientific Veterinary Institute "Novi Sad", Serbia

${ }^{3}$ Faculty of Agriculture, University of Belgrade, Serbia

\begin{abstract}
Cyprinidae, the largest known fish family including carp and minnows, has worldwide distribution with many species that are economically important in aquaculture. As would be expected, many viral pathogens can affect this group. The most pathogenic of these are the rhabdoviruses, a reovirus and three herpesviruses. Cyprinid herpesviruses can cause significant economic losses in aquaculture, and some of these viruses are oncogenic. The three herpesviruses are closely related but cause distinctly different diseases. Fish pox, caused by cyprinid herpesvirus 1 (CyHV-1), is one of the oldest known fish diseases, being recorded as early as 1563. It takes the form of a hyperplastic, epidermal papilloma on common carp. Cyprinid herpesvirus $2(\mathrm{CyHV}-2)$ is causative agent of herpesviral hematopoietic necrosis (HVHN). The herpesvirus was first isolated from cultured goldfish in Japan. It causes a severe epizootic but no external clinical signs were apparent on affected fish. One of the most economically important and researched viral diseases of carp is koi herpesviral disease caused by cyprinid herpesvirus 3 (CyHV-3). The aim of this paper is to present the current knowledge on herpesvirus diseases of the cyprinids.
\end{abstract}

Key words: cyprinids, CyHV-1, CyHV-2, CyHV-3

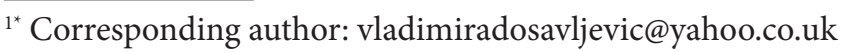




\section{HERPESVIRUSNE BOLESTI CIPRINIDA}

Vladimir Radosavljevićc ${ }^{*}$, Jelena Maksimović-Zorić ${ }^{1}$, Ljubiša Veljović ${ }^{1}$, Dragana Ljubojević ${ }^{2}$, Miroslav Ćirković ${ }^{2}$,Zoran Marković ${ }^{3}$, Vesna Milićević ${ }^{1}$

${ }^{1}$ Naučni institut za veterinarstvo Srbije, Beograd, Serbia

${ }^{2}$ Naučni institut za veterinarstvo "Novi Sad", Serbia

${ }^{3}$ Poljopreivredni fakultet, Univerzitet u Beogradu, Srbija

\section{Kratak sadržaj}

Ciprinide, najveća poznata familija riba, koja obuhvata šaranske vrste riba, je rasprostranjena širom sveta, sa mnogim vrstama koje imaju veliki ekonomski značaj u akvakulturi. Kao što bi se moglo očekivati, mnogi virusi mogu delovati na ovu grupu, među kojima su od najvećeg značaja pripadnici familija rabdovirusa, reovirusa i herpesvirusa. Herpesvirusi ciprinida mogu izazvati značajne ekonomske gubitke u akvakulturi, a neki od njih virusa su onkogeni. Iako su veoma srodni herpesvirusi ciprinida izazivaju različite bolesti sa veoma različitim karakteristikama. Boginje riba, koje izaziva herpesvirus 1 (CyHV-1), je jedno od najstarijih poznatih bolesti riba, utvrđeno još 1563. godine. Ovo oboljenje se po pravilu ispoljava u vidu hiperplastičnih papilomatoznih promena epiderma šarana. Herpesvirus 2 (CyHV-2) je uzročnik herpesvirusne hematopoezne nekroze (HVHN). Ovaj virus je prvi put izolovan iz zlatnih ribica u Japanu. Kao posledica delovanja uzročnika dolazi do pojave značajnih epizootija bez izraženih kliničkih znakova kod obolelih riba. Jedno od ekonomski najznačajnijih virusnih oboljenja šarana je koi herpesviroza izazvana ciprinim herpesvirusom 3 (CyHV-3). Cilj ovog rada je da se predstave aktuelna saznanja o oboljenjima ciprinida izazvanih herpesvirusima.

Ključne reči: ciprinidi, CyHV-1, CyHV-2, CyHV-3

\section{INTRODUCTION}

Herpesviruses constitute a large group of large DNA virus with the same structure and biological properties of the virion (McGeoch et al., 2008). They are host-specific pathogens. The family Herpesviridae contains mammalian, avian and reptilian viruses; the family Alloherpesviridae contains herpesviruses of fish and amphibians, and the family Malacoherpesviridae comprises single 
invertebrate herpesvirus (Ostreid herpesvirus). The family of Alloherpesviridae is highly diverse, with a genome size ranging from $134 \mathrm{kbp}$ of channel catfish virus - the smallest sequenced genome, to $295 \mathrm{kbp}$ of cyprinid herpesvirus-3, which is the largest known genome among the order Herpesvirales (McGeoch et al., 2006; Davison, 2010). The members of the fam. Alloherpesviridae are widespread among the fish and frogs and are grouped into four families: $\mathrm{Ba}$ trachovirus, Cyprinivirus, Ictalurivirus and Salmonivirus (Davison et al., 2009). Genus Cyprinivirus includes four viruses: eel herpesvirus 1 (AngHV-1) isolated from the European eel (Anguilla anguilla), and three cyprinid herpesvirus (CyHV-1, CyHV CyHV-2 and-3) (Hanson et al., 2011). These viruses are capable of causing serious diseases in cyprinids. Size of the genome of these viruses is 291.144 bp (CyHV-1), 290304 bp (CyHV-2) and 295,146 bp (CyHV3 ), and their genomes have a $80 \%$ homology (Aoki et al., 2007; Davison et al., 2013). Herpesvirus virion consists of four morphologically distinct portions: the core, which consists of a linear double-stranded DNA; icosahedral capsid; protein coating; and lipid envelope with viral proteins (Davison, 2010).

\section{CYPRINID HERPESVIRUS-1 (CyHV-1)}

Cyprinid herpesvirus 1, also known as a carp pox virus, causes benign papillomatous lesions in the epithelium of common carp, Cyprinus carpio, and its ornamental form koi (Plumb and Hanson, 2011). This virus was detected in fish in most European countries, the USA, Israel, Russia, and parts of Asia (China, Japan, Korea, and Malaysia). In Serbia, this disease is present and represents one of the most common diseases of cultivated carp in the area of Vojvodina (Jeremić et al., 2005). The changes are initially flat, solid, smooth and transparent, but soon become thicker and resemble drops of paraffin on the skin. Further proliferation leads to the formation of papillomatous formation of an irregular shape, with thickness of 4 to 6 millimeters. They become milky white to gray in color, sometimes with a pink hue that comes from capillary vasodilation. The lesions may be present in different parts of the body but usually begin in the fins. Proliferated cells are not invasive and do not metastasize. Infected adults show no change in behavior or clinical signs; however, in younger fish, CyHV-1 infection can lead to clinically manifested disease with high mortality. In infected carp fry, loss of appetite, dilatation of abdomen, exophthalmos, bleeding on operculum and abdomen and dark skin pigmentation may occur (Plumb and Hanson, 2011). Growth retardation and emaciation are continuously present signs of the disease in advanced cases. The tail of such carp can be easily bent to touch its head. Such flabby fish have a reduced 
muscular tone and osteomalatia with very low levels of ash, calcium and phosphorus in the vertebrae. After recovering, deformations of the spine are often visible. The disease is seasonal and lesions usually occur when the water temperature drops below $15^{\circ} \mathrm{C}$, and disappear with the rise in temperature. Sano et al. (1993) showed that the CyHV-1 genome is present in the nervous system and the subcutaneous tissue after the termination of the disease, suggesting that the virus becomes latent, which may explain the recurrence of lesions in the convalescent fish. Virus has not been isolated from diseased carp. However, herpesvirus was isolated from koi carp on FHM cell line at $15^{\circ} \mathrm{C}$ in Japan. It has been demonstrated that this virus, like other herpes viruses, is lethal to juvenile carp and the survivors, after several months, develop papilomatous changes characteristic of carp pox. Japanese CyHV-1 isolate did not cause disease in grass or crucian carp (Sano et al., 1991).

\section{CYPRINID HERPESVIRUS-2 (CyHV-2)}

Cyprinid herpesvirus-2 (CyHV-2) is the causative agent of the disease called herpes hematopoietic necrosis (HVHN). Although it does not cause massive epizootic, it is clear that $\mathrm{CyHV}-2$ is present globally and very prevalent in populations of goldfish.

The disease occurs when the fish are exposed to stress and the water temperature allows the replication of the virus. The disease was first identified in Japan in 1992 and 1993 in goldfish (Carassius auratus) (Jung and Miyazaki, 1995). Later, the occurrence of the disease in goldfish has been reported worldwide, in the USA (Groff et al., 1998; Goodwin et al., 2006), Taiwan (Chang et al., 1999), Australia (Stephens et al., 2004), the UK (Jeffery et al., 2007), China (Li et al., 2013), Switzerland, Germany (Haenen et al., 2016), France (Boitard et al., 2016). Recently, the disease in crucian carp (C. carassius) and Prussian carp (C. gibelio) caused by CyHV-2 has been found in several European and Asian countries (Danek et al., 2012; Luo et al., 2013; Fichi et al., 2013; Ito and Maeno, 2014). The presence of the CyHV-2 virus was not detected in susceptible fish populations in the fishfarms of the Republic of Serbia. Although it is generally accepted that $\mathrm{CyHV}-2$ has been circulating in populations of goldfish around the world for a long time (Goodwin et al., 2006; Waltzek et al., 2009; He et al., 2013) the exact mechanism of its occurrence in the new host is not completely clear. In an outbreak of the disease in the goldfish, diseased fish do not show typical signs of the disease. The only noticeable changes are apathy and pallor of gills, with hypertrophy and hyperplasia of the gill epithelium. Internally, spleen and kidney necrosis are present (Jung and Miyazaki, 1995; 
Groff et al., 1998). The disease incidence is dependent on the temperature of the water and occurs between $15-25^{\circ} \mathrm{C}$, with a mortality rate of $50-100 \%$ (Groff et al., 1998). In the outbreak of the disease in Prussian carp, diseased fish are lethargic, with dark skin pigmentation and stay on the bottom of the pond. The disease occurs at 20 to $30^{\circ} \mathrm{C}$ and disappears when the water temperature rises above $30^{\circ} \mathrm{C}$ (Luo et al., 2013). In addition, the virus caused neither death nor symptoms of the disease in silver or bighead carp. Bearing in mind the increasing number of cases that indicate the spread of the virus as well as the fact that CyHV-2 can infect other species of the genus Carassius, knowledge of its characteristics and application of preventive measures is of vital importance.

\section{CYPRINID HERPESVIRUS-3 (CyHV-3)}

The disease caused by Cyprinid herpesvirus-3 (CyHV-3), named koi herpesvirus disease (KHVD), was first described in Germany in 1997 (Bretzinger et al., 1999), and shortly thereafter in Israel and the United States (Hedrick et al., 2000). There is evidence that CyHV-3 has been present in carp in the UK since 1996 (Aoki et al., 2007).

The disease is present in our neighboring countries, and the latest cases were recorded in Croatia in 2016, in Czech Republic in 2016, in Romania in 2017 (OIE, 2017). The assumption that the virus is present in carp populations in Serbia is established in 2004, when a high mortality of one-year and two-year-old carp on three ponds on the territory of the Republic of Serbia was recorded. In two fish farms, mortality of one-year and two-year-old carp was observed in the spring, with clinical symptoms and pathomorphological alterations characteristic to KHV (Jeremic and Radosavljevic, 2007).

Since CyHV-3 causes a disease in all age groups (Hedrick et al., 2000) with huge mortality - up to $100 \%$, it is considered to be the major viral pathogen in carp. The disease seriously challenges the trade of ornamental koi and carp production worldwide (Rakus et al., 2013) bearing in mind that the common carp is the world's fourth most-farmed fish (Ronen et al., 2003).

Based on sequence analysis of CyHV-3 isolated worldwide, Kurita et al. (2009) have determined the existence of the Asian (two variants) and the European genotype (seven varieties).

The outcome of the infection is highly dependent on water temperature, and deaths occur within water temperature range from $18-25^{\circ} \mathrm{C}$ (Gilad et al., 2003 ) to $17-26^{\circ} \mathrm{C}$ (Haenen et al., 2004) or $17-28^{\circ} \mathrm{C}$ (Ilouze et al., 2006). The maximum water temperature tolerated by the virus is $28^{\circ} \mathrm{C}$ (Gilad et al., 2003). Undoubtedly, the disease occurs most often in spring, with a water tempera- 
ture increase (Hedrick et al., 2000), and is primarily due to the inability of the immune response, suppressed by low temperatures in winter, to adequately react to the replication of the virus.

In studies of the virus ability to survive in water, Perelberg et al. (2003) found that CyHV-3 causes the death of fish within 4 hours after the addition of the virus into the water, while the virus loses its activity after 21 hours. It was found that the virus persists in water for 3 to 7 days after inoculation (Shimizu et al., 2006), as well as to survive longer in fish feces and mud (Dishon et al., 2005).

The study of Minamoto et al. (2011) revealed that in $90.3 \%$ of river water samples viral DNA was present 4-5 years after the onset of the disease, i.e., that 5 years after the occurrence of the disease all rivers in Japan were contaminated with $\mathrm{CyHV}-3$. The same authors found that this virus is present in the plankton in outbreak waters.

In addition, CyHV-3 DNA can be present in approximately 100-fold higher concentration in sediment than in water, suggesting that the sediment can be a reservoir of the virus (Honjo et al., 2012). The skin of carp acts as the portal of entry of CyHV-3 and the site of early replication (Costes et al., 2009). The early replication of the virus at the portal of entry could contribute not only to the spread of the virus within infected fish but also to the spread of the virus throughout the fish population. On the third day after infection, the fish cease feed intake and become lethargic. After that, nervous signs of infection appear (shaking, twitching, uncoordinated movements, erratic swimming in shallow water). Also, infected fish rub against other fish or against objects. Such behavior could contribute to a skin-to-skin mode of transmission. To date, no evidence of vertical transmission of CyHV-3 has been found. Death occurs within three to four days after the onset of these signs, about 7 days after infection (Hedrick et al., 2000).

Among clinical signs endophtalmus, areas of pale patches on the skin, increased mucus secretion, multifocal loss of the epidermis giving the skin a "sandpaper-like texture" and changes to the gills in the form of irregular discoloration of the gills, swelling and necrosis of gills are present (Pikarsky et al., 2004; Gilad et al., 2004).

In clinically healthy fish, CyHV-3 can remain latent and the infection can be reactivated by temperature stress (Gilad et al., 2004; Eide et al., 2011).

\section{CONCLUSIONS}

Most of herpes viruses in fish cause a mild infection in natural environment, but in the intensive aquaculture these viruses can cause serious diseases 
with high mortality. Since the number of identified herpesviruses in fish increases, development of effective prophylactic measures and control of these diseases became much more important.

\section{ACKNOWLEDGEMENT}

This study was financially supported by a grant from the Ministry of Education, Science and Technology development of the Republic of Serbia, under the project TR31075, TR-31011.

\section{REFERENCES}

1. Aoki T, Hirono I, Kurokawa K, Fukuda H, Nahary R, Eldar A, Davison AJ, Waltzek TB, Bercovier H, Hedrick R: Genome sequences of three koi herpesvirus isolates representing the expanding distribution of an emerging disease threatening koi and common carp worldwide. Journal of Virology, 81, 10, 5058-5065, 2007.

2. Boitard P.-M., Baud M., Labrut S., de Boisséson C., Jamin M., Bigarré, L.: First detection of Cyprinid Herpesvirus 2 (CyHV-2) in goldfish (Carassius auratus) in France. Journal of Fish Diseases, 39, 673-680, 2016.

3. Bretzinger A., Fischer-Scherl T., Oumouna M., Hoffmann R., Truyen U.: Mass mortalities in koi, Cyprinus carpio, associated with gill and skin disease. Bulletin-European Association of Fish Pathologists, 19, 5, 182-185, 1999.

4. Chang P.H., Lee S.H., Chiang H.C.,Jong M.H.: Epizootic of herpes-like virus infection in goldfish, Carassius auratus in Taiwan. Fish Pathology, 34, 209-210, 1999.

5. Costes B, Stalin Raj V, Michel B, Fournier G, Thirion M, Gillet L, Mast J, Lieffrig F, Bremont M, Vanderplasschen, A.: The major portal of entry of Koi Herpesvirus in Cyprinus carpio is the skin. Journal of Virology, 7, 28192830, 2009.

6. Danek T., Kalous L., Vesely T., Krasova E., Stanislava R.S., Rylkova K., Kulich P., Petrty M., Pokorova D., Martin K.: Massive mortality of Prussian carp Carassius gibelio in the upper Elbe basin associated with herpesviral hematopoietic necrosis (CyHV-2). Diseases of Aquatic Organisms, 102, 87-95, 2012.

7. Davison A.J., Eberle R., Ehlers B., Hayward GS., McGeoch D.J., Minson A.C.: The order Herpesvirales. Archives of Virology, 2009.

8. Davison A.J.: Herpesvirus systematics. Veterinary Microbiology, 143, 5269, 2010. 
9. Dishon A., Perelberg A., Bishara-Shieban J., Ilouze M., Davidovich M., Werker S., Kotler M.: Detection of carp interstitial nephritis and gill necrosis virus in fish droppings. Applied and Environmental Microbiology, 71, 7285-7291, 2005.

10. Eide K.E., Miller-Morgan T., Heidel J.R., Kent M.L., Bildfell R.J., La Patra S., Watson G., Jin L.: Investigation of koi herpesvirus latency in koi. Journal of Virology, 85, 4954-4962, 2011.

11. Fichi G., Cardeti G., Cocumelli C., Vendramin N., Toffan A., Eleni C., Siemoni N., Fischetti R., Susini F.: Detection of Cyprinid herpesvirus 2 in association with an Aeromonas sobria infection of Carassius carassius (L.), in Italy. Journal of Fish Diseases, 36, 823 - 830, 2013.

12. Gilad O., Yun S., Adkison M.A., Way K., Willits N.H., Bercovier H., Hedrick R.P.: Molecular comparison of isolates of an emerging fish pathogen, koi herpesvirus, and the effect of water temperature on mortality of experimentally infected koi. Journal of General Virology, 84, 2661-2668, 2003.

13. Gilad O., Yun S., Zagmutt-Vergara F.J., Leutenegger C.M., Bercovier H., Hedrick R.P.: Concentrations of a koi herpesvirus (KHV) in tissues of experimentally infected Cyprinus carpio koi as assessed by real-time TaqMan PCR. Diseases of Aquatic Organisms, 60, 179-187, 2004.

14. Goodwin A.E., Merry G.E., Sadler J.: Detection of the herpesviral hematopoietic necrosis disease agent (Cyprinid herpesvirus 2) in moribund and healthy goldfish: validation of a quantitative PCR diagnostic method. Diseases of Aquatic Organisms, 69, 137-143, 2006.

15. Groff J.M., LaPatra S.E., Munn R.J., Zinkl J.G.: A viral epizootic in cultured populations of juvenile goldfish due to a putative herpesvirus etiology. Journal of Veterinary Diagnostic Investigation, 10, 375-378, 1998.

16. Hanson L., Dishon A., Kotler M.: Herpesviruses that infect fish. Viruses, 3 , 2160-2191, 2011.

17. Haenen O.L.M., Way K., Bergmann S.M., Ariel E.: The emergence of koi herpesvirus and its significance to European aquaculture. Bulletin of the European Association of Fish Pathologists, 24, 293-307, 2004.

18. Haenen O., K. Way, B. Gorgoglione, T. Ito, R. Paley, L. Bigarré, T. Walcek: Novel viral infections threatening Cyprinid fish. Bulletin of the European Association of Fish Pathologists, 36, 1, 11. 2016.

19. Hedrick R.P., Gilad O., Yun S., Spangenberg J., Marty R., Nordhausen M.: A herpesvirus associated with mass mortality of juvenile and adult koi, a strain of common carp. Journal of Aquatic Animal Health, 12, 44-57, 2016.

20. He J., Shi X., Yu L., Zheng X., Lan W., Jia P., Wang J., Liu H.: Development and evaluation of a loop-mediated isothermal amplification assay for di- 
agnosis of Cyprinid herpesvirus 2. Journal of Virological Methods, 194, 206-210, 2013.

21. Honjo M.N., Minamoto T., Kawabata Z.: Reservoirs of Cyprinid herpesvirus 3 (CyHV-3) DNA in sediments of natural lakes and ponds. Veterinary Microbiology, 155, 183-190, 2012.

22. Ilouze M., Dishon A., Kotler M.: Characterization of a novel virus causing a lethal disease in carp and koi. Microbiology and Molecular Biology Reviews, 70, 147-156, 2006.

23. Ito T., Maeno Y.: Susceptibility of Japanese Cyprininae fish species to cyprinid herpesvirus 2 (CyHV-2). Veterinary Microbiology, 169, 128-134, 2014.

24. Jeffery K.R., Bateman K., Bayley A., Feist S.W., Hulland J., Longshaw C., Stone D., Woolford G., Way K. Isolation of a cyprinid herpesvirus 2 from goldfish, Carassius auratus (L.), in the UK. Journal of Fish Diseases, 30, 649-656, 2007.

25. Jeremić S., Ćirković M., Jakić-Dimić D., Radosavljević V. Bolesti riba na šaranskim ribnjacima i realno sprovođenje mera zdravstvene zaštite. Veterinarski glasnik, 59, 1-2, 59-69, 2005.

26. Jeremić S., Radosavljević V. Koi herpesvirusno oboljenje šarana. Veterinarski glasnik, 61, 1-2, 53-64, 2007.

27. Jung S.J., Miyazaki T.: Herpesviral haematopoietic necrosis of goldfish, Carassius auratus (L.). Journal of Fish Diseases, 18, 211-220, 1995.

28. Li L.J., Luo Y.Z., Liu X.Q., Gu Z.M., Yuan J.F.: Molecular surveillance of Cyprinid herpesvirus 2 in goldfish cultured in China. Journal of Huazhong Agricultural University, 32, 92-96, 2013.

29. Luo Y., Lin L., Liu Y., Wu Z., Gu Z., Li L., Yuan J.: Haematopoietic necrosis of cultured Prussian carp, Carassius gibelio (Bloch), associated with Cyprinid herpesvirus 2. Journal of Fish Diseases, 36, 1035-1039, 2013.

30. Minamoto T., Honjo MN., Yamanaka H., Tanaka N., Itayama T., Kawabata Z.: Detection of cyprinid herpesvirus-3 DNA in lake plankton. Research in Veterinary Science, 90,530-532, 2011.

31. McGeoch D.J., Davison A.J., Dolan A., Gatherer D., Sevilla-Reyes E.: Molecular evolution of the Herpesvirales. In: Domingo E, Parrish CR \& Holland JJ (Eds): Origin and evolution of viruses, 2nd edition. Oxford Elsevier, pp. 447-475. 2008.

32. OIE World Animal Health Information Database, http://www.oie.int/wahis_2/public/wahid.php/Diseaseinformation/Diseasetimelines

33. Perelberg A, Smirnov M, Hutoran M, Diamant A, Bejerano Y, Kotler M.: Epidemiological description of a new viral disease afflicting cultured Cyprinus carpio in Israel. The Israeli Journal of Aquaculture-Bamidgeh, 55, 5-12, 2003. 
34. Pikarsky E, Ronen A, Abramowitz J, Levavi-Sivan B, Hutoran M, Shapira Y, Steinitz M, Perelberg A, Soffer D, Kotler M.: The pathogenesis of acute viral diseases in fish induced by the carp interstitial nephritis and gill necrosis virus. Journal of Virology, 78, 9544-9551, 2004.

35. Plumb J.A., Hanson L.A.: Carp and minnow viruses. In: Plumb JA, Hanson LA (Eds): Health maintenance and principal microbial diseases of cultured fishes, 3rd edition. Blackwell Publishing pp. 109-134, 2011.

36. Rakus K., Ouyang P., Boutier M., Ronsmans M.: Cyprinid herpesvirus 3: an interesting virus for applied and fundamental research. Veterinary Research, 44, 85, 2013.

37. Ronen A., Perelberg A., Abramowitz J., Hutoran M., Tinman S., Bejerano I., Steinitz M., Kotler M.: Efficient vaccine against the virus causing a lethal disease in cultured Cyprinus carpio. Vaccine, 21, 4677-4684, 2003.

38. Sano N., Moriwake M., Hondo R., Sano T.: Herpesvirus cyprini: a search for viral genome in infected fish by in situ hybridization. Journal of Fish Diseases, 16, 495-499, 1993.

39. Sano, T., Morita, N., Shima, N., Akimoto, M.: Herpesvirus cyprini: lethality and oncogenicity. Journal of Fish Diseases, 14, 533-43, 1991.

40. Shimizu T., Yoshida N., Kasai H., Yoshimizu M.: Survival of koi herpesvirus (KHV) in environmental water. Fish Pathology, 41, 153-157, 2006.

41. Stephens F.J., Raidal S.R., Jones B.: Haematopoietic necrosis in a goldfish (Carassius auratus) associated with an agent morphologically similar to herpesvirus. Australian Veterinary Journal, 82, 167-169, 2004.

42. Waltzek T.B., Kurobe T., Goodwin A.E., Hedrick R.P.: Development of a polymerase chain reaction assay to detect cyprinid herpesvirus 2 in goldfish. Journal of Aquatic Animal Health, 21, 60-67, 2009.

Primljeno: 03.05.2017.

Odobreno: 21.06.2017. 